М.С. Четверик /д.т.н./,

О.А. Бубнова /к.Т.н./,

К.С. Левченко
Інститут геотехнічної механіки

ім. М.С. Полякова НАН України,

м. Дніпро, Україна

\title{
ВИКОРИСТАННЯ ПРОСТОРІВ ВІДПРАЦЬОВАНИХ КАР'СРІВ ДЛЯ ЗАБЕЗПЕЧЕННЯ ЕНЕРГЕТИЧНОЇ НЕЗАЛЕЖНОСТІ ГІРНИЧОДОБУВНИХ РЕГІОНІВ
}

\author{
M.S. Chetveryk/Dr. Sci. (Tech.)/, \\ O.A. Bubnova/Cand. Sci. (Tech.)/, \\ K.S. Levchenko
}

Institute of Geotechnical Mechanics named by N. Poljakov of National Academy of

Sciences of Ukraine, Dnipro, Ukraine

\section{USE OF EXHAUSTED QUARRIES SPACES TO ENSURE THE ENERGY INDEPENDENCE OF MINING REGIONS}

Мета. Обгрунтування можливості забезпечення енергетичної незалежності гірничодобувних регіонів за рахунок використання просторів відпрацьованих кар'єрів для виробництва електроенергії та економічної ефективності доопрацювання кар'єрів із одночасним створенням в них маломодульних атомних електростаниій.

Методика. Аналіз застосовуваних у світі енергетичних систем, заснованих на використанні енергї атома, дозволив обтрунтувати створення маломодульних атомних електростанцій у просторах відпрацьованих кар'єрах.

Результати. Обтрунтовано вид енергетичного комплексу, щио розмішується в кар'єрі, тип атомного реактора, його потужність і безпека. Розглянута можливість спорудження атомної станиії з одночасним веденням гірничих робіт. Обгрунтовано розташування атомного реактора, при якому б досягалося мінімальне забруднення навколишнього середовища. Встановлено економічну та соиіальну ефективність створення атомної станиії в кар'єрі.

Наукова новизна. Вперше показано можливість розміщення атомної електростаниї у просторі відпрацьованого кар'єру із забезпеченням ї̈ ресурсами, створенням екологічно безпечної роботи та економічної і соиіальної ефективності.

Практична цінність. Запропонований варіант розміщуення міні атомної електростанції у просторі кар 'єру одночасно з його доопрацююванням має сочіальну, економічну та екологічну ефективність. Соціальна ефективність складається у перепрофілюванні кар 'єру та забезпечення зайнятості населення. Екологічна ефективність полягає у зменшенні екологічного навантаження та рекультивації об'єктів гірничорудного комплексу. Економічна ефективність складається із зменшення собівартості руди, щуо буде видобуватись при доопраџююванні кар'єру, та близько 1 млрд. доларів операційного прибутку від експорту електроенергї, яку може виробити проектована електростаниія.

Ключові слова: відпрацьований кар'єр, атомна енергетика, маломодульні атомні електростаниії, екологічність, економічна ефективність.

DOI: $10.34185 / 0543-5749.2019-5-6-3-11$

Вступ. Екологічний стан планети постійно погіршується і левову частку в його погіршення вносить енергетичний комплекс у вигляді теплових електростанцій і гірничих розробок з видобутку вугілля. Порушення екологічного стану навколишнього середовища настільки великі, що вони прийняли необоротний характер. Особливо ця проблема актуальна для України, де досить великий відсоток електроенергіі, що виробляється тепловими електростанціями.

Споживання електроенергії збільшується 3 розвитком науково-технічного прогресу і збільшенням чисельності населення.

На підставі прогнозу збільшення населення

(C) Четверик М.С., Бубнова О.А., Левченко К.С., 2019 
Миру і його зменшення в Україні, а також зростання споживання електроенергії на душу населення виконано прогноз потреби в електроенергії: до 2030 року в світі потреба в електроенергії складе 55 х 1012 кВт.год, в Україні - 330 х 109 кВт.год (при нинішніх показниках $25 \times 1012$ кВт.год $\mathrm{i}$ 210 х 109 кВт.год відповідно для Світу і України) [1]. Тому необхідна потужність електростанцій повинна збільшитись 3 7,5 x 109 кВт до $13,7 \times 109$ кВт для Світу і $355 \times 106$ до 82,5 x 106 для України.

Збільшення виробництва електроенергії призведе до погіршення екологічного стану. Тому актуальним $є$ завдання розробки концепції збільшення виробництва електроенергії із забезпеченням екологічної безпеки.

Аналіз літературних даних та постановка проблеми. Як зазначає автор роботи [2] для забезпечення роботи найбільшої в світі теплової електростанції в Белхатуві (Польща) влада 3 2015 по 2019 pр. збільшила дозвіл на викид вуглецю на $250 \%$, що істотно відбилось на екологічній ситуації. Екологічна модернізація Белхатувської електростанції призвела до підвищення вартості електроенергії на $39 \%$. У той же час операційний прибуток компанії скоротився на $26 \%$. Отже, модернізація теплових електростанцій не ефективна 3 точки зору забезпечення економічної та екологічної стабільності.

В аналітичному звіті Американського Фонду «Чисте небо» [3] вказується на необхідність переоснащення застарілих теплових електростанцій 3 переходом на інші джерела палива. Крім поновлюваних джерел енергії в світі розробляють інші концепції. Наприклад, автори роботи [4] пропонують отримувати біоенергію 3 кореневищ рослин. Автори публікації [5] відзначають, що основним напрямком заміни теплової електроенергетики є маломодульні атомні реактори.

В Україні активно розвивається сонячна енергетика. Так, в січні 2019 р. ввели в експлуатацію найбільшу сонячну електростанцію в Україні (третя за потужністю в Європі), яка розташовується на ділянці колишнього рудного кар'єру біля c. Старозаводське Нікопольського району Дніпропетровської області. Потужність $246 \mathrm{MBT}$ забезпечують 750 тис. панелей, встановлених на 400 га землі. Позитивним в цьому є використання просторів відпрацьованих кар'єрів та виробництво енергії в екологічно безпечний спосіб. В той же час негативним $€$ те, що для виробництва 1 МВт енергії необхідна площа більш ніж 1,6 га.

Тому для умов України необхідним є обгрунтування стратегії переходу на інші види енергії.

Мета і завдання досліджень. Враховуючи встановлену раніше [6] зміну в часі енергетичного забезпечення, для України розвиток енергетичної системи з урахуванням зниження впливу на навколишнє середовище можливо тільки шляхом зміни виду енергетичного забезпечення, а світовий перехід до атомної енергетики зумовлює цей напрям як найбільш перспективний i економічне (рис. 1).

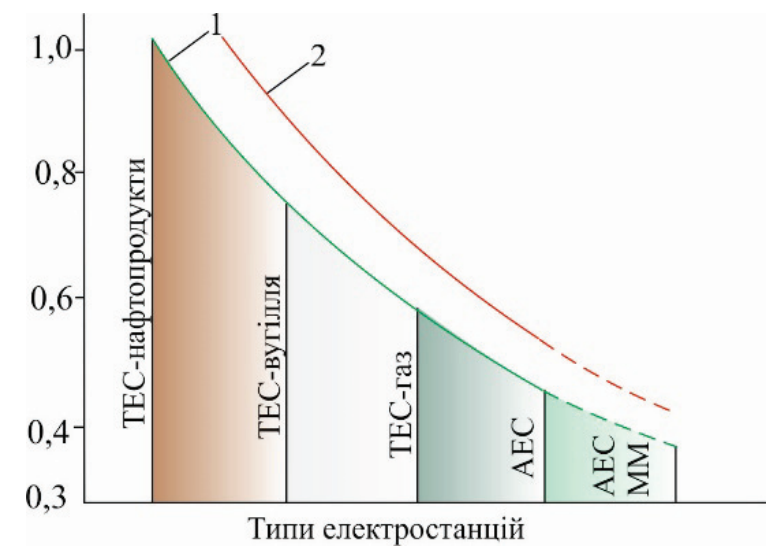

Рис. 1. Вартість виробництва однієї кіловатгодини електроенергії різними типами електростанцій (в частках одиниці від «ТЕС-Нафтопродукти»): 1 - мінімальна; 2 - максимальна, прогнозована

В той же час в Україні близько 300 виведених з експлуатації і нерекультивованих кар'єрів, простори яких можливо використати для виробництва енергії.

Тому метою роботи є обгрунтування можливості забезпечення енергетичної незалежності гірничодобувних регіонів за рахунок використання просторів відпрацьованих кар'єрів для виробництва електроенергії.

Завданнями дослідження $є$ аналіз розвитку енергетичних систем, заснованих на використанні енергії атома та обгрунтування доцільності й економічної ефективності створення маломодульних атомних електростанцій на прикладі Ганнівського кар'єру Північного ГЗК в процесі його доопрацювання.

Матеріали та методи дослідження. Потужні атомні електростанції, які почали застосовувати в середині минулого століття, 3 досвіду будівництва i експлуатації характеризуються низкою недоліків, таких як:

- великі капітальні вкладення, тривалі терміни будівництва (досягають 5 - 10 років), що збільшує собівартість виробленої ними електроенергії;

- ризик радіаційного забруднення величезних територій при аваріях на великих атомних електростанціях (чим вище потужність атомної 
електростанції, тим більшу територію очікує можливе забруднення).

Проведений аналіз атомних реакторів і їх параметрів, які розроблені в останні роки в США, Японії, Франції, Китаї, Росії, свідчить про наступне. В атомній енергетиці розвиваються два головних напрямки:

1 - розробка і створення атомних реакторів на швидких нейтронах (замість реакторів на теплових нейтронах, які використовують в існуючих АЕC);

2 - створення і використання міні атомних електростанцій із маломодульними реакторами (AEC MMP).

В існуючих атомних станціях використовують високо збагачений уран і утворюються відходи. В ядерних реакторах на швидких нейтронах крім основного виділення енергії за рахунок поділу ${ }^{235} \mathrm{U}$, відбувається додаткове - в результаті нейтронного випромінювання і перетворення ${ }^{238} \mathrm{U}$ в ${ }^{239} \mathrm{Pu}$, який також є ядерним паливом. Це дозволяє досягти замкнутого ядерного циклу, при якому відсутні відходи. У цих ядерних реакторах може бути використаний збіднений уран, який залишається в результаті виробництва високозбагаченого урану для військових цілей або як ядерне паливо. Також перевагою $є$ відсутність сповільнювачів, які охолоджуються теплоносієм. Відповідно до досліджень [7] в реактоpax на швидких нейтронах також можна використовувати відходи перероблено ядерного палива.

Атомні електростанції потужністю 1000 МВт і менше називають «міні». У ряді країн розробляють проекти і створюють міні-АЕС потужністю від 10 до 1000 МВт. На відміну від великих атомних електростанцій, малі модульні ядерні реактори мають елементи пасивної безпеки, засновані на фізичних законах. Малі модульні ядерні реактори виробляють на заводах і транспортують до місця розміщення. Це знижує вартість і терміни будівництва. Міні атомні електростанції такого типу створюють на основі ядерних реакторів, які використовують в атомних підводних човнах, криголамах і ін. Ці реактори безпечні, тривалий період працюють при одній заправці ядерним паливом. Наприклад, американський mPower - це компактний легководний реактор потужністю 125 МВт розміром 24 на 6 м і масою 500 т, який розміщують під землею. Його завантаження паливом здійснюють раз в п'ять років.

Пропонувалось будівництво електростанції з 4-6 модулів mPower, яка повинна замінити вугільну ТЕС в Ноксвілл (штат Теннесі, США), що закривається. Загалом у США планують закрити протягом найближчого десятиліття близь- ко 100 вугільних енергоблоків і замінити їх на міні-АЕC.

В Японії розроблено проект атомного реактоpa $4 \mathrm{~S}$ - Super-Safe, Small, Simple (найбезпечний, маленький, простий). Це заглиблений в землю на 30 м циліндр, в який завантажується ядерне паливо, що складається з суміші металевого урану, плутонію і цирконію. Він може функціонувати протягом 30 років на одній заправці ядерного палива [8]. До цього напрямку належить ядерний реактор Нyperion, потужністю $70 \mathrm{MBT}$ i ін.

Аналіз існуючих маломодульних атомних електростанцій та їх характеристик дозволив виділити можливі напрямки їх використання в Україні:

- як автономне енергетичне забезпечення віддалених районів;

- в якості автономного енергетичного забезпечення підприємств.

- для заміни існуючих вугільних ТЕС міні атомними модульними електростанціями, що складаються з декількох блоків.

$\mathrm{У}$ той же час можливий ризик аварій на міні AEC зумовлює обмеження щодо їх розміщення. Враховуючи наявність в Україні великої кількості відпрацьованих кар'єрів, та тих, експлуатація яких завершиться в найближчі 10 років, дозволяє визначити їх простори ідеальними для розміщення в них енергетичних комплексів.

Результати дослідження. На прикладі Ганнівського кар'єру Північного ГЗК, який розміщується біля м. Терни та 3 усіх боків межує із об'єктами гірничорудного комплексу Криворіжжя, обгрунтовано розміщення у виробленому просторі кар'єру міні АЕС.

Перспективи розвитку гірничих робіт $у$ Ганнівському кар'єрі. Ганнівський кар'єр розробляє витягнутий (близько 8 км) крутопадаючий поклад неокислених залізистих кварцитів складної будови і якості руди. На кар'єрі застосовують комплекс циклічно-потокової технології (ЦПТ), конвеєрний тракт якого розташований на тимчасово неробочому борту кар'єра, законсервував частину запасів руди і поділив кар'єр на дві ділянки: північну і південну. На південній ділянці поклад руди більшої потужності. Подальше зниження гірничих робіт для видобутку руди потребують виїмки значних обсягів розкриву з неминучим збільшенням відстані транспортування, що негативно відіб'ється на собівартості руди та відповідно збільшенні собівартості концентрату. Розвитку гірничих робіт в західному напрямку перешкоджають зовнішні відвали, а в східному - існуючі транспортні комунікації. Гірничі роботи здійснюють при глибині 
350 - 380 м, а гранична глибина кар'єру може бути близько $450-500$ м, яка може буде досягнута за 15 - 20 років. При доопрацюванні кар'єра до граничної глибини, за економічними показниками, його простір поступово буде заповнено високомінералізованою водою, в результаті чого підвищиться випаровування, що призведе до зміни мікроклімату.

Виходячи 3 цього, в просторі відпрацьованого кар'єру можна розмістити різні енергетичні комплекси, наприклад, гідроакумулюючу [9] або атомну електростанцію, що дозволить:

- підвищити економічну ефективність роботи підприємства шляхом створення незалежного автономного енергетичного забезпечення;

- продовжити роботу Ганнівського кар'єру шляхом зміни спрямованості (експортувати не концентрат, а електроенергію) та вирішити соціальну проблему із зайнятістю населення;

- поліпшити екологічний стан району шляхом припинення видобутку руди і рекультивації кар'єру і відвалів.

Слід відзначити, що відповідно до досліджень вчених-екологів [10-11], які порівняли шкідливість ТЕC та АEC, теплова енергетика $\epsilon$ більшим забруднювачем довкілля та шкідником для здоров'я населення.

Обтрунтування вибору атомного реактора $i$ його розташування. Атомну електростанцію і атомний реактор доцільно приймати виходячи 3 наступного. Виробництво залізорудної продукції (концентрат, окатиші, агломерат) досить енергоємне (на одну тонну концентрату витрачається близько 45 кВт.год електроенергіi). Тому атомний реактор повинен мати достатньо велику потужність. Кар'єр і відвали розкривних порід займають велику земельну площу, насичені транспортними комунікаціями, деякі ділянки схильні до зсувних процесів. Тому при виборі місця розміщення AEC і атомного реактора необхідно враховувати ці особливості. Атомна станція i атомний реактор повинні бути перспективними на кілька десятків років. Необхідно прийняти такий атомний реактор, який добре апробований за тривалий період експлуатації.

Проведений аналіз параметрів і застосування атомних реакторів різних виробників (Росії, США, Японія, Китай та ін.) свідчать про наступне. В існуючих атомних станціях використовують реактори на теплових нейтронах. При їх використанні потрібен високо збагачений уран, і утворюються відходи. Розглядалася можливість розміщення в кар'єрі ядерного реактора СВБР-100 i ядерного реактора КЛТ-40. Перевагою цих реакторів є висока безпека і тривалий період роботи
(5 - 10 років) при одному завантаженні ядерним паливом. Однак вони мають малу потужність, мають ряд суттєвих інших недоліків. Перспективним і досить апробованим є атомні реактори на швидких нейтронах типу БН, які застосовують тривалий час в Росії на Белоярській АЕС. Викиди радіоактивних речовин для АЕС з РУ типу БН становлять частки відсотка, від допустимих.

Реактори типу БН можуть використовувати в якості палива оксидне, щільне і інші види палива. Головний енергоблок БН-1200 виконаний за принципом моноблока: один реактор - одна турбіна. Система технічного водопостачання для енергоблоку БН-1200 прийнята зворотня, з використанням для охолодження технічної води однієї баштової випаровувальної градирні великої продуктивності. Енергоблок БН-1200 призначений для роботи в енергосистемі в базовому режимі. Міні AEC, обладнана реакторною установкою БН-1200 займає розмір 0,4 км², а санітарно-захисна зона приймається рівною огорожі майданчика AEC. Безпека такого реактора заявлена виробником із зазначенням можливих меж доз опромінення населення при аваріях:

- при проектній аварії (протікання газової системи 1 контуру) - менше 1 м3в/рік;

- при запроектній аварії (аварія ULOF) 5 мЗв.

Будівлю реактора скомпоновано 3 урахуванням радіального розташування основного обладнання по відношенню до РУ і виконано у вигляді циліндричного обсягу. Центральним об'ємом будівлі є реакторне відділення циліндричної форми, перекрите сферичним куполом, відмітка верху $+81,0$. Будівельна частина АEC розроблена 3 урахуванням землетрусу (MP3) інтенсивністю 7 балів за шкалою MSK-64 і 3 урахуванням зовнішніх природних i техногенних впливів. Циліндрична компоновка будівлі реактора дозволяє врахувати можливість падіння літака масою до 400 т.

Проектні рішення зі створення атомної станції в Ганнівському кар'єрі. Необхідну потужність атомної електростанції доцільно прийняти виходячи із забезпечення електроенергією:

- всього технологічного комплексу Північного ГЗК;

- населення в 30 км зоні безкоштовної електроенергією з урахуванням переходу на електричне опалення і забезпечення гарячою водою;

- експорту електроенергії в обсягах, які б дозволили отримати стільки ж або більше виручки, ніж при експорті залізорудної продукції в обсягах відповідних продуктивності кар'єра.

Потужність теплових електростанцій Украї- 
ни коливається від 260 - 800 МВт (Сєвєродонецька, Слов'янська) до 3600 МВт (Вуглегірська, Криворізька). Виходячи 3 цього, потужність атомної електростанції можна прийняти (середню) 2400 МВт. Це відповідає потужності двох атомних енергоблоків БН-1200. При проектуванні енергоблока тільки для виробничих потреб Північного ГЗК достатньо потужності електростанції близько 100 МВт, що відповідає потужності ядерного реактора СВБР-100.

Атомні електричні станції є великими споживачами води, основна кількість якої надходить в конденсатори парових турбін для конденсації відпрацьованої пари. Тому необхідним $\epsilon$ створення в кар'єрі спеціальних водойм для забезпечення атомної електростанції водою. Сумарна витрата охолоджуючої води (технічної) при використанні турбіни К-1200-130/3000 для одного енергоблоку з урахуванням витрат і на інші потреби становить $2,5 \mathrm{x} 105 \mathrm{~m}^{3} /$ год.

В роботі розглядаються два варіанти створення атомної електростанції в Ганнівському кар'єрі:

- перший - створення AЕС в кар'єрі проводиться в дві черги. При цьому передбачається доробка південної ділянки кар'єра. Зберігається комплекс циклічно-потокової технології (ЦПТ) при створенні першої черги;

- другий - створення AEC в кар'єрі проводиться з урахуванням ліквідації комплексу ЦПТ. На цій ділянці створюються Північна і Південна дамби.

Суть першого варіанту полягає в наступно- му. Виходячи 3 прийнятої потужності, приймається створення атомної електростанції в кар'єрі, що складається 3 двох енергоблоків БН-1200. Їх будівництво і введення в експлуатацію слід здійснювати в дві черги. 3 метою забезпечення безпеки і незалежності роботи атомних електростанцій їх спорудження проводиться на різних ділянках кар'єра.

I черга. 3 огляду на розвиток гірничих робіт в кар'єрі, положення зовнішніх відвалів розкривних порід, атомну електростанцію першої черги 3 енергоблоком БН-1200 передбачається розмістити на північній ділянці кар'єра (рис. 2).

Атомний реактор (див. рис. 2) розміщується частково в скельних і м'яких породах на відм. +100 м. Над поверхнею (відмітка +150 м) буде виступати 30 м пристрою. Площа атомної елект-

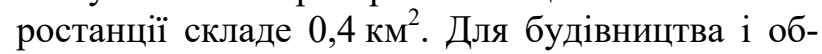
слуговування використовуватиметься існуюча залізнична колія. Для забезпечення електростанції водою в північній частині передбачено створення водойми. На горизонті +100 м на відстані більше 100 м від маркшейдерської осі 4,0 поперечно кар'єру споруджується дамба. Новоутворена ємність глибиною 180 м та об'ємом 51 млн. м ${ }^{3}$ екранується і заповнюється водою.

II черга. Після пуску в експлуатацію першої черги, здійснюють будівництво АЕС другої черги. Ядерний реактор і атомна електростанція розташовуються між західним бортом кар'єра і відвалом (рис. 3). Південну частину кар'єра передбачено розділити дамбою 7. При цьому утворюються дві водойми 11 і 12 (див. рис. 3).

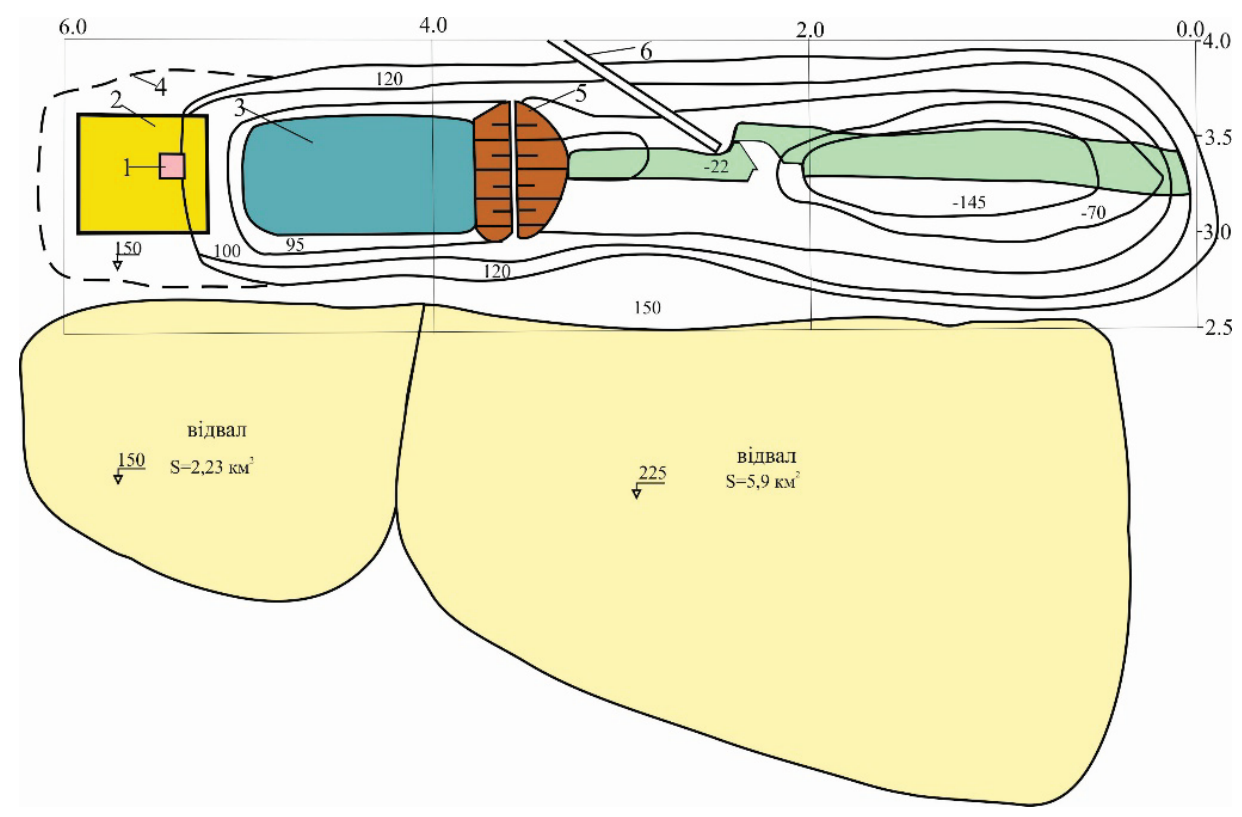

Рис. 2. Схема розташування атомної станції (перший варіант, і черга) 3 енергоблоками БН-1200 на північній ділянці Ганнівського кар'єру: 1 - атомний реактор; 2 - атомна станція; 3 - водойма; 4 залізнична колія; 5 - дамба; 6 - конвеєрний тракт комплексу ЦПТ 
Водойма 11 не екранується і до неї надходять підземні і поверхневі води. Водойма 12 екранується, в ній розміщуються прісні води, після опріснення мінеральних вод кар'єра, що надходять 3 водойм 3 i 11 . Смність водойми складає 58 млн.м ${ }^{3}$. Згідно даних проектного інституту ВАТ «СПбАЕП» при експлуатації атомних електростанцій $з$ атомними реакторами БН-
1200 немає необхідності в створенні санітарної зони. Для безпеки досить огорожі.

Суть другого варіанта розміщення міні AEC в кар'єрі полягає в наступному. Дамби споруджуються на місці цілини під конвеєрним підйомником ЦПТ (рис. 4), а ядерні реактори і атомні електростанції розташовуються між зовнішніми відвалами і кар'єром.

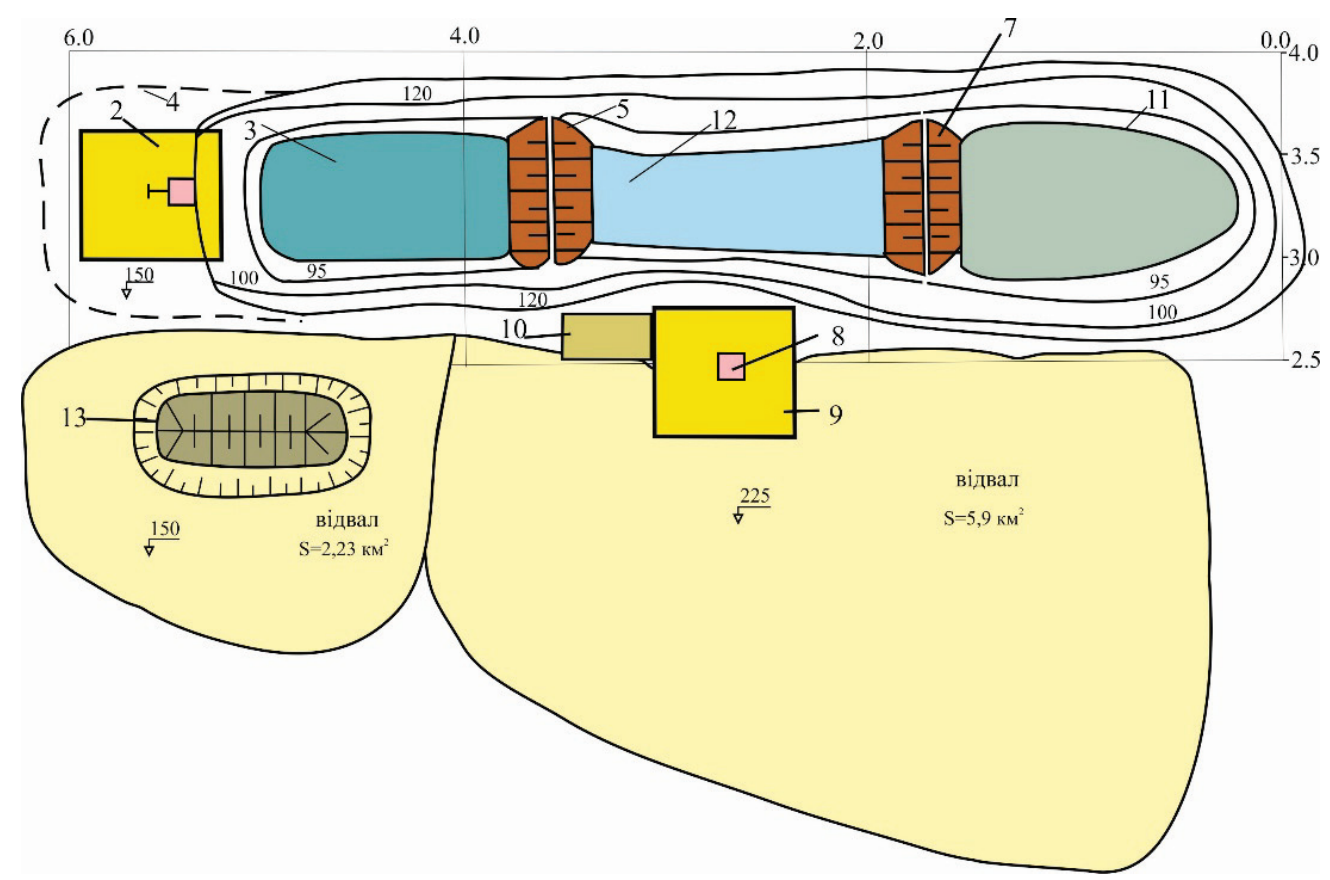

Рис. 3. Створення в кар'єри АЕС II черги (перший варіант): 1 - 6 - див. рис. $2 ; 7$ - дамба; 8 - атомний реактор; 9 - атомна електростанція; 10 - опріснювальні пристрої; 11 - водойма природної мінеральної води; 12 - водойма прісної води; 13 - відвал солей, що утворилися при опрісненні води

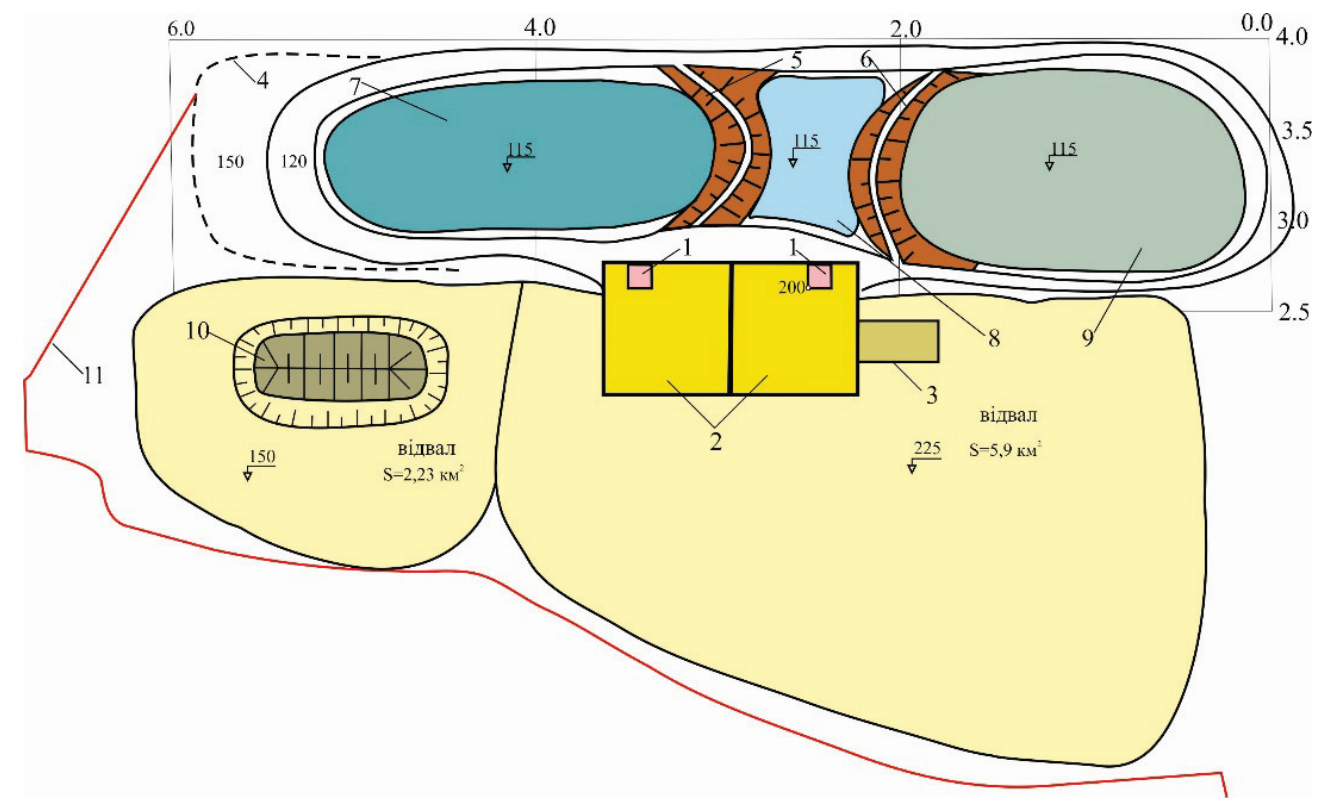

Рис. 4. Створення в кар'єри АЕС, другий варіант: 1 - ядерні реактори БН-1200; 2 - атомні електростанції; 3 - опріснювальні пристрої; 4 - залізнична колія; 5 - дамба Північна; 6 - дамба Південна, 7 - водойма технічної води; 8 - водойма прісної води; 9 - водойма мінеральної води; 10 - відвал солей, що утворилися при опрісненні води; опріснювальні пристрої; 11 - межа гірничого відводу 
Перевагою цього варіанту $є$ те, що викиди інертних газів повністю залишаються в чаші кар'єра, оскільки ядерні реактори (верх) обмежені відвалом висотою понад 100 м.

Обговорення результатів. Створення атомної станції в Ганнівському кар'єрі дозволить вирішити ряд екологічних та соціальних проблем:

1) будівництво атомної електростанції буде здійснюватися протягом 7 - 10 років. Для будівництва буде затребуване значна кількість робочої сили, а також техніки, що використовується на кар'єрі;

2) наявність великих об'ємів прісної води дозволить здійснити рекультивацію відвалів кар'єру;

3) зменшиться споживання електроенергії ПівнГЗК від існуючої енергомережі, та може бути вирішено питання іï експорту;

4) слід також врахувати, що радіація в відвальної золі і золі виносу біля теплових електростанцій вище, ніж при атомних.

Слід зазначити, що в цій роботі розглянуто створення атомної електростанції на швидких нейтронах як перспективний напрямок. Але можливе створення атомних електростанцій іншого типу.

Визначимо економічну ефективність створення AEC в Ганнівському кар'єрі по чергах їх створення (економічні розрахунки виконані за цінами 2014 року).

Для визначення економічної ефективності I черги приймаємо: продуктивність Ганнівського кар'єру - 14 млн т руди на рік або 4.2 млн. т концентрату. Відповідно до статистичних даних України по Мінпаливенерго виручка від експорту 1 т концентрату складає 90 доларів. Встановлена потужність AEC I черги - 1220 МВт. Кількість годин роботи $\mathrm{AEC} \mathrm{-} \mathrm{T}=7896$ год.

При вищеописаних показниках виручка від експорту залізорудного концентрату Ек складе Ек $=4,2 \cdot 10^{6} \cdot 90=378 \cdot 10^{6}$ дол.

При заданих показниках буде вироблено електроенергії $\mathrm{E}_{\text {пр }}$

$\mathrm{E}_{\text {пр }}=\mathrm{N} \cdot \mathrm{T}=7896 \cdot 1220=9,6 \cdot 10^{6} \mathrm{MBT}$.

3 них на власні потреби АЕС приймаємо $10 \%$. Тоді

$$
\begin{gathered}
\mathrm{A}=\mathrm{E}_{\text {пр }} \cdot 0,9=9,6 \cdot 10^{6} \cdot 0,9=8669808 \mathrm{MBT} \\
\text { або } 8,7 \cdot 10^{6} \mathrm{MBт.}
\end{gathered}
$$

На потреби Північного ГЗК при продуктивності 15 млн. т концентрату і витраті електроенергії на рівні 40 кВт год/т

$\mathrm{H}_{\text {гзк }}=15 \cdot 10^{6} \cdot 40=600 \cdot 10^{3}$ МВт.год.

Приймаємо кількість годин роботи підпри- ємства 7000. Тоді необхідна потужність електростанції для Північного ГЗК складе

$$
\mathrm{N}_{\text {гзк }}=600 \cdot 103 / 7000=86 \mathrm{MBT} \text {. }
$$

Можна прийняти $\mathrm{N}_{\text {гзк }}=100$ МВт.

На потреби населення (орієнтовно) - 0,5 МВт.

Експорт електроенергії за вирахуванням внутрішнього споживання складе 8,05 · 109 кВт. Виручка від експорту 1 кВт електроенергії становить 0,06 доларів. Тоді виручка від експорту електроенергії $\mathrm{E}_{\mathrm{e}}$ складе

$$
\mathrm{E}_{\mathrm{e}}=8,05 \cdot 10^{9} \cdot 0,06=483 \cdot 10^{6} \text { доларів. }
$$

Таким чином, виручка від експорту електроенергії при створенні першої черги АЕC більша за виручку від експорту концентрату.

Виручка від експорту електроенергії спільно з другою чергою АЕС складе близько 1 мільярда доларів на рік.

Згідно 3 експертними оцінками, середньосвітова ціна за кіловат потужності середньої i малої генерації становить близько 5,5 тисячі доларів. Тоді вартість споруди однієї атомної станції складе 6,6 мільярда доларів, а двох 13,2. Таким чином, вартість атомної електростанції, що складається 3 двох атомних реакторів, в разі експорту електроенергії може бути окуплена протягом 12 - 13 років. Однак при цьому необхідно враховувати можливості передачі електроенергії енергетичними лініями за кордон.

Висновки. 1. Створення атомних електростанцій у просторі відпрацьованих кар'єрів, біля відвалів розкривних порід дозволяє викиди інертних газів повністю розмістити в чаші кар'єра, оскільки верхню частину ядерного реактора можна обмежити відвалом або верхніми уступами кар'єра. Це підвищить їх екологічну безпеку.

2. Економічно ефективно в Україні замість експорту залізорудного концентрату експортувати електричну енергію, що дозволить отримувати щорічну виручку близько 1 мільярда доларів на рік. На прикладі створення атомної електростанції на Ганнівському кар'єрі потужністю 2400 МВт показано, що це дозволить не тільки заповнити втрати від закриття нерентабельного кар'єру, але і значно знизити витрати на виробництво залізорудної продукції на Першотравневому кар'єрі і Першотравневому руднику, а також забезпечить безкоштовною електроенергією частину населення.

3. Перепрофілювання кар'єра дозволяє вирішити соціальні проблеми шляхом працевлаштування вивільненого населення.

4. Зменшиться екологічне навантаження на навколишнє середовище.

5. Можливі й інші варіанти розміщення 
електростанцій і їх типів в техногенних геологічних середовищах.

\section{Бібліографічний список}

1. Chetverik M.S. Structural changes in economy when energy systems changing. Metallurgical and Mining industry. 2018. № 2. C. 23-31.

2. Wynn G., Coghe P. To Embrace a Profitable Energy Future, Poland's PGE Must Abandon Plans for a New Lignite Mine. Institute for Energy Economics and Financial Analysis. IEEFA.org. 2019. URL: http://ieefa.org/wp-content/uploads/2019/10/ PGE-Must-Abandon-Plans-for-a-New-Lignite-Mine _October-2019.pdf.

3. American Clean Skies Foundation, 2011. Repurposing Legacy Power Plants: Lessons for the Future. Washington, D.C. URL: http://www. potomacrivergreen.org/wpcontent/uploads/2016/01/ ACSF_layout_coverANDtext.pdf.

4. David P.B.T.B. Strik, H.V.M. Hamelers (Bert), Jan F.H. Snel, Cees J. N. Buisman. Green electricity production with living plants and bacteria in a fuel cell. International Journal Of Energy Research. Int. J. Energy Res. 2008. Vol. 32, Issue 9. P. 870-876. DOI: http://doi.org/10.1002/er.1397.

5. Granger Morgan, Ahmed Abdulla, Michael J. Ford, Michael Rath. US nuclear power: The vanishing low-carbon wedge. PNAS. July 10, 2018, Vol. 115, No 28. P. 7184-7189. DOI: https://doi. org/10.1073/pnas. 1804655115

6. Четверик М.С., Мішіна О.В. Розвиток енергетичних систем світу та їх вплив на стабільний стан економіки і суспільства. Розробка родовищ 2014: щорічний науково-технічний збірник / ред. кол.: В.І. Бондаренко та ін.Дніпропетровськ : ЛізуновПрес, 2014. С. 519526.

7. William H. Hannum, Gerald E. Marsh, George S. Stanford. Smarter Use of Nuclear Waste. Scientific American. December 2005. URL: https://nationalcenter.org/NuclearFastReactorsSA12 05.pdf.

8. Brown, N. W., et al., Liquid metal cooled reactors and fuel cycles for international security, ICONE-11 (Proc. 11th Int. Conf. on Nuclear Engineering, Tokyo, Japan, 2003), ASME.

9. Спосіб доробки кар'єру : патент на КМ 22470А. МПК Е21С 41/00. № 95073414; заявл. 20.07.1995; опубл. 30.06.1998, Бюл. № 3.4 с.

10. Гордиенко В. А., Брыкин С. Н., Кузин Р. Е., Серебряков И. С., Старкова М. В., Таиров Т.Н. Атомная энергетика: за или против? Сравнительный анализ радиоактивного загрязнения, создаваемого АЭС и ТЭС, работающими на угле. Вестник Московского универ- ситета. Серия 3. Физика. Астрономия. 2012. № 1. C. 123-130.

11. Энергетика: история, настоящее и будущее. Кн. 5. Электроэнергетика и охрана окружающей среды. Функционирование энергетики в современном мире / Бурячок Т. А. и др. ; науч. ред.: Клименко В. Н., Ландау Ю. А., Сигал И. Я. Киев : [б. и.], 2011. 391 с.

\section{References}

1. Chetverik, M. S. (2018). Structural changes in economy when energy systems changing. Metallurgical and Mining industry, (2), 23-31.

2. Wynn, G., \& Coghe, P. (2019). To Embrace a Profitable Energy Future, Poland's PGE Must Abandon Plans for a New Lignite Mine. Institute for Energy Economics and Financial Analysis. Retrieved from: http://ieefa.org/wp-content/uploads/ 2019/10/PGE-Must-Abandon-Plans-for-a-NewLignite-Mine_October-2019.pdf.

3. Repurposing Legacy Power Plants: Lessons for the Future. (2011). American Clean Skies Foundation, Washington, D.C. Retrieved from: $\mathrm{http}: / / \mathrm{www}$. cleanskies.org/?publication=repurposin g-legacy-power-plants-lessons-for-the-future.

4. Strik, D.P.B.T.B., Hamelers (Bert), H.V.M., Snel, J.F.H., \& Cees, J. N. (2008). BuismaGreen electricity production with living plants and bacteria in a fuel cell. International Journal Of Energy Research. doi: 10.1002/er.1397.

5. Morgan, G., Abdulla A., Ford, M.J., \& Rath M. (2018). US nuclear power: The vanishing lowcarbon wedge, PNAS, July 10, 115(28), 7184-7189. doi: 10.1073 /pnas. 1804655115

6. Chetverik, M.S., \& Mishyna, O.V. (2014). Evolution of world energy systems and their impact on stable condition of economy and society. Rozrobka rodovyshch. Dnipro, 519-526.

7. Hannum, W. H., Marsh, G. E., \& Stanford, G. S. (2005). Smarter Use of Nuclear Waste. Scientific American, December, Retrieved from: https://nationalcenter.org/NuclearFastReactorsSA12 05.pdf

8. Brown, N.W. et al. (2003). Liquid metal cooled reactors and fuel cycles for international security, ICONE-11, Proc. 11th Int. Conf. on Nuclear Engineering. Tokyo, Japan: ASME.

9. Chetverik, M.S., Kosenko, V.I., \& Derevyanko, V.I. (1998). UA Patent No. 22470A. Kiev.

10. Gordienko, V.A., Brykin, S.N., Kuzin, P.E., Serebryakov, I.S., Starkova, M.V., \& Tairov, T.N. (2012). Atomnaia Enerhetyka Za Ili Protyv? Sravnytelnyi analyz radyoaktyvnoho zahriaznenyia sozdavaemoho AES i TES rabotaiushchymy na uhle. Vestnyk Moskovskoho Unyversyteta. Seryia 3. 
Fyzyka. Astronomyia, (1), 123-130.

11. Buryachok, T. A. et al.; ed.: Klimenko, V. N., Landau, Yu. A., \& Sigal I. Ya. (2011). Energetika: istoriya, nastoyashchee $i$ budushchee. Vol. 5. Elekrtoenergetika I okhrana okruzhaushchey sredy. Funkstionirovanie energetiki v sovremennom mire. Kiev.

Цель. Обоснование возможности обеспечения энергетической независимости горнодобывающих регионов за счет использования пространств отработанных карьеров для производства электроэнергии и экономической эффективности доработки карьеров с одновременным созданием в них маломодульних атомных электростанций.

Методика. Анализ применяемых в мире энергетических систем, основанных на использовании энергии атома позволил обосновать создание маломодульных атомных электростанциий в пространствах отработанных карьеров.

Результаты. Обоснован вид энергетического комплекса, который предлагается разместить в карьере, тип атомного реактора, его мошность и безопасность. Рассмотрена возможность сооружения атомной станции $c$ одновременным ведением горных работ. Обоснованно расположение атомного реактора, при котором бы достигалось минимальное загрязнение окружающей среды. Установлена экономическая и социальная эффективность атомной станции в карьере.

Научная новизна. Впервые показана возможность размещения атомной электростанијии в пространстве отработанного карьера с обеспечением ее ресурсами, созданием экологически безопасной работы, экономической и социиальной эффективности.

Практическая ценность. Предложенный вариант размещения мини атомной электростанции в пространстве карьера одновременно c его доработкой имеет сочиальную, экономическую и экологическую эффективность. Сочиальная эффективность состоит в перепрофилировании карьера и обеспечения занятости населения. Экологическая эффективность заключается в уменьшении экологической нагрузки и рекультивации объектов горнорудного комплекса. Экономическая эффективность состоит из уменьшения себестоимости руды, которая будет добываться при доработке карьера, и около 1 млрд. долларов операчионной прибыли от экспорта электроэнергии, которую может произвести проектируемая электростанция.

Ключевые слова: отработанный карьер, атомная энергетика, маломодульные атомные электростанции, экологичность, экономическая эффективность.

Purpose. Substantiation of the possibility of ensuring the energy independence of the mining regions by utilizing the open-cast quarries for electricity production and the economic efficiency of the refinement of the quarries with the simultaneous creation of small-scale nuclear power plants in them.

Methods. An analysis of the energy systems used in the world based on the use of atomic energy made it possible to justify the creation of lowmodulus nuclear power plants in spent quarries.

Results. The type of quarry energy complex, the type of nuclear reactor, its capacity and safety are substantiated. The possibility of constructing a nuclear power plant with simultaneous mining operations is considered. The location of the nuclear reactor at which minimal environmental pollution would be achieved is substantiated. The economic and social efficiency of the creation of a nuclear power plant in the quarry has been established.

Originality. For the first time, the possibility of placing a nuclear power plant in the space of a spent quarry with the provision of its resources, creation of environmentally safe work and economic and social efficiency is shown.

Practical implications. The proposed option of placing a mini-nuclear power plant in the quarry space at the same time as its refinement has social, economic and environmental efficiency. Social efficiency is about redefining careers and securing employment. Eco-efficiency is the reduction of environmental load and the reclamation of mining facilities. Cost-effectiveness consists of reducing the cost of ore to be mined while quarrying, and about $\$ 1$ billion in operating income from electricity exports that a projected power plant can produce.

Key words: spent quarry, nuclear power, small-module nuclear power plants, environmental friendliness, cost-effectiveness.

Рукопис надійшов 05.11.2019 